\title{
Optimasi Travelling Thief Problem Menggunakan Algoritma Tree Physiology Optimization Berbasis Hiper Heuristik
}

\author{
Lanang Alun Nugraha*1, Ahmad Muklason ${ }^{2}$ \\ ${ }^{1,2}$ Jurusan Sistem Informasi Teknologi Sepuluh November \\ e-mail: *lanang.18052@mhs.its.ac.id
}

\begin{abstract}
Abstrak
Travelling thief problem (TTP) merupakan gabungan dari permasalahan travelling salesman problem dan knapsack problem. travelling thief problem sendiri merupakan permasalahan NP-Hard sehingga permasalahan sebagian besar diselesaikan menggunakan algoritma heuristic dan terus berkembang seiring berjalanya waktu.. Algoritma yang digunakan pada penelitian ini adalah simple random untuk pemilihan low level heuristic $(L L H)$ dan tree physiology optimization (TPO) untuk langkah move acceptance dengan menggunakan model Hyper-Heuristics. Pada penelitian yang telah dilakukan sebelumnya algoritma TPO mampu menghasilkan nilai yang cukup kompetitif dengan waktu komputasi yang baik, sedangkan pemodelan Hyper-Heuristics dapat menghasilkan nilai yang konsisten pada data yang beragam. Penelitian diawali dengan memodelkan algoritma TPO menjadi Hyper-Heuristics dan diuji coba dengan data dari TSPLib. Dari hasil uji coba yang dilakukan dapat dilihat bagaimana performa algoritma baru pada data yang diuji. Berdasarkan hasil yang didapat dari penelitian ini dapat disimpulkan bahwa algoritma LLH TPO dapat mengolah data TTP dengan ukuran di bawah 100 dengan cukup baik terbukti dengan hasil yang lebih baik dari metode genetic programming based hyper-heuristic (GPHS) yang telah ada sebelumnya, namun pada data di atas 100 performa LLH TPO menurun jika dibandingkan dengan metode GPHS.
\end{abstract}

Kata kunci-Travelling Thief Problem, Tree Physiology Optimization, Hyper-Heuristic

\begin{abstract}
Ttraveling thief problem is a combination of the traveling salesman problem and the knapsack problem. traveling thief problem itself is an NP-Hard problem, so most of the problems are solved using a heuristic algorithm and it continues to grow over time. The algorithm used in this study is simple random for the selection of low level heuristics (LLH) and tree physiology optimization (TPO) for the move acceptance step using the Hyper-Heuristics model.. In previous research, the TPO algorithm is able to produce competitive values with good computation time, while Hyper-Heuristics modeling can produce consistent values on various data. The research was started by modeling the TPO algorithm into Hyper-Heuristics and tested it with data from TSPLib. From the results of the trials conducted, it can be seen how the performance of the new algorithm on the data being tested. Based on the results obtained from this study, it can be concluded that the LLH TPO algorithm can process TTP data with sizes below 100 quite well, as evidenced by better results than the previous genetic programming based hyper-heuristic (GPHS) method, but the data above 100 LLH TPO performance decreased when compared to the GPHS method.
\end{abstract}

Keywords - Travelling Thief Problem, Tree Physiology Optimization, Hyper-Heuristic 


\section{PENDAHULUAN}

Travelling Thief Problem (TTP). TTP merupakan permasalahan yang dirancang dengan menggabungkan antara Travelling Salesman Problem (TSP) dan Knapsack Problem (KP). Permasalahan ini pertama kali diusulkan oleh boyandi [1] pada tahun 2013. Permasalahan TTP termasuk dalam permasalahan NP-Hard karena tidak memungkinkan untuk penyelesaian menggunakan metode exact dalam waktu yang terbatas. Karena termasuk dalam permasalahan NP-Hard maka penyelesaian yang digunakan untuk TTP merupakan pengembangan dari metode heuristic. Penyelesaian permasalahan menggunakan metode yang berdasar pada heuristic bertujuan untuk mendapatkan hasil yang cukup hingga baik dengan waktu pengerjaan yang terbatas.

Travelling Salesman Problem (TSP) merupakan permasalahan kombinatorial NP-Hard yang terus berkembang. TSP sendiri merupakan permasalahan untuk menemukan cara terbaik untuk mengunjungi semua kota dan kembali ke titik awal yang meminimalkan jarak perjalanan atau biaya perjalanan [2]. Data dari TSP merupakan seperangkat kota dan seperangkat biaya atau jarak perjalanan antar setiap pasangan yang memungkinkan. Knapsack Problem (KP) adalah permasalahan untuk membawa beberapa barang dengan ukuran yang berbeda dengan nilai yang berbeda ke dalam sebuah ransel dengan volume tertentu dengan tujuan memaksimalkan profit atau nilai barang yang dibawa [3]. Dari kedua permasalahan tersebut dihasilkan permasalahan TTP yang bertujuan untuk memberikan model benchmark yang lebih mendekati masalah optimasi yang sebenarnya dalam berbagai situasi, di mana permasalahan tersebut terdiri dari sub-sub masalah yang saling berinteraksi [4].

Penelitian untuk permasalahan TTP telah dilakukan dan berkembang dalam beberapa tahun ke belakang. Penelitian yang dilakukan dalam penyelesaian permasalahan TTP menggunakan berbagai macam algoritma yang dikembangkan. Penelitian yang dilakukan oleh Junhua $\mathrm{Wu}$ [5] menyelesaikan permasalahan TTP dengan membandingkan tiga algoritma berbeda menghasilkan bahwa metode Dynamic Programming yang diusulkan menghasilkan solusi yang optimal di sebagian besar data berukuran sedang dan kecil yang digunakan. Penelitian lainya dilakukan oleh Mohamed El Yafrani [4] menyelesaikan permasalahan TTP menggunakan metode Genetic Programming Base Hyper-Heuristics (GPHS) yang dibandingkan dengan beberapa metode yang lain. Hasil dari penelitian ini adalah bahwa algoritma yang diusulkan mendapatkan hasil yang kompetitif dibandingkan algoritma lain. Selain permasalahan TTP penelitian sebelumnya tentang permasalahan TSP yang merupakan bagian dari permasalahan TTP juga dilakukan. Penelitian yang dilakukan oleh Halim dan Ismail [6] membandingkan beberapa algoritma heuristic pada permasalahan Travelling Salesman Problem. Dari penelitian tersebut disimpulkan bahwa algoritma dengan waktu komputasi tercepat adalah Nearest Neighbor (NN). Untuk algoritma yang menghasilkan nilai mendekati optimum adalah Tabu Search (TS). Studi lain oleh Halim dan Ismail [7] yang meneliti tentang penyelesaian masalah TSP dan Benchmark Function Characteristics menggunakan algoritma Tree Physiology Optimization(TPO) dan membandingkan dengan beberapa algoritma lainya. Dari penelitian ini disimpulkan bahwa pada permasalahan TSP, TPO menghasilkan nilai yang dapat dibandingkan dengan Genetic Algorithm(GA).

Selain dari permasalahan TTP dan turunannya, dilakukan juga eksplorasi pada penelitian yang menggunakan mode hyper-heuristic. Pada penelitian oleh Bacha [8] yang meneliti tentang penyelesaian permasalahan Permutation Flow Shop Problem dengan menggunakan metode Hyper-Heuristic Genetic Algoritm. Hasil dari penelitian ini adalah metode Hyper-Heuristic Genetic Algoritm dapat menyelesaikan 50 dari 120 data permasalahan dengan hasil paling optimal dan menghasilkan nilai yang kompetitif pada data yang lainya. Penelitian lain oleh Choong dan Li-Pei Wong [9] yang mengusulkan metode Hyper-Heuristic

Lanang Alun Nugraha, et., al [Optimasi Travelling Thief Problem Menggunakan Algoritma Tree Physiology Optimization Berbasis Hiper Heuristik] 
dengan otomatisasi desain pada komponen high level heuristic dengan menggunakan $Q$ learning untuk menetapkan komponen yang ada. Metode yang diusulkan tersebut digunakan untuk menyelesaikan enam domain permasalahan yaitu, Boolean Satisfiability (SAT), Onedimensional Bin-Packing (BP), Permutation Flow Shop (FS), Personnel Scheduling (PS), Traveling Salesman Problem (TSP) dan Vehicle Routing Problem (VRP). Model QHH yang diusulkan dapat menyelesaikan tiga puluh contoh benchmark dari enam domain masalah di HyFlex dengan baik.

Berdasarkan penelitian yang telah ada sebelumnya penyelesaian permasalahan TTP masih terus berkembang. Pada perkembangan penelitian tersebut belum ada penggunaan metode TPO dengan model hyper-heuristic untuk penyelesaiannya. Pada penelitian yang dilakukan pada penelitian [6] TPO sendiri merupakan algoritma nomor dua dengan komputasi tercepat setelah NN dan nomor nilai paling mendekati optimal setelah TS pada permasalahan TSP. Dari situ algoritma TPO masih dapat dikembangkan untuk menyelesaikan permasalahan TTP yang merupakan gabungan TSP dan Knapsack Problem. Untuk pengembangan yang dilakukan pada penelitian adalah menggunakan TPO dalam model hyper-heuristic. Dengan menggunakan model hyper-heuristic diharapkan dapat meningkatkan performa dalam berbagai data yang beragam. Data yang digunakan pada penelitian ini didapatkan dari TSPLib yang juga digunakan pada penelitian [4]. Contoh data yang digunakan dapat dilihat pada tabel 1.

Tabel 1. Contoh Data TTP

\begin{tabular}{|c|c|c|c|}
\hline \multicolumn{2}{|l|}{ NAME } & \multicolumn{2}{|c|}{ eil51-TTP } \\
\hline KNAPSACK DATA TYPE & \multicolumn{3}{|c|}{ Uncorrelated } \\
\hline \multicolumn{2}{|l|}{ NUMBER OF ITEMS } & \multicolumn{2}{|c|}{50} \\
\hline \multicolumn{2}{|c|}{ CAPACITY OF KNAPSACK } & \multicolumn{2}{|c|}{2226} \\
\hline \multicolumn{2}{|c|}{ DIMENSION } & \multicolumn{2}{|c|}{51} \\
\hline \multicolumn{2}{|l|}{ MIN SPEED } & \multicolumn{2}{|c|}{0.1} \\
\hline MAX SPEED & & \multicolumn{2}{|c|}{1} \\
\hline RENTING RATIO & & \multicolumn{2}{|c|}{7.19} \\
\hline \multicolumn{2}{|l|}{ EDGE_WEIGHT_TYPE } & \multicolumn{2}{|c|}{ CEIL_2D } \\
\hline \multicolumn{4}{|c|}{ NODE_COORD_SECTION } \\
\hline 1 & & 37 & 52 \\
\hline 2 & & 49 & 49 \\
\hline \multicolumn{2}{|l|}{3} & 52 & 64 \\
\hline & & • & $\cdot$ \\
\hline 51 & & 30 & 40 \\
\hline \multicolumn{4}{|c|}{ ITEMS SECTION } \\
\hline INDEX & PROFIT & WEIGHT & $\begin{array}{c}\text { ASSIGNED } \\
\text { NODE } \\
\text { NUMBER }\end{array}$ \\
\hline 1 & 119 & 1 & 2 \\
\hline 2 & 187 & 896 & 3 \\
\hline 3 & 997 & 367 & 4 \\
\hline - & - & - & - \\
\hline 50 & 509 & 885 & 51 \\
\hline
\end{tabular}




\section{METODE PENELITIAN}

Penelitian ini dilakukan dengan melalui beberapa tahapan yaitu desain algoritma, implementasi, dan analisis hasil.

\section{1 Desain Algoritma}

Pada desain algoritma ini terbagi menjadi empat bagian yaitu konversi format data, penetapan solusi awal, seleksi pemilihan low level heuristic (LLH), dan penggunaan langkah move acceptance. Pada desain algoritma ini akan menggunakan sepuluh low level heuristic dengan simple random sebagai metode pemilihannya, sedangkan untuk langkah move acceptance menggunakan algoritma tree physiologi optimization (TPO).

\section{1.1 Konversi Format Data}

Data yang digunakan merupakan data TTP dengan format umum seperti pada tabel 1. Berdasarkan data tersebut diperlukan konversi untuk mengubah titik koordinat kota menjadi jarak antar kota. Oleh karena itu setiap titik koordinat antar kota dihitung menggunakan rumus euclidean distance dan dibulatkan ke atas agar sesuai dengan format yang dapat diolah dalam metode.

\section{1.2 Inisialisasi Solusi Awal}

Solusi awal yang digunakan dalam menentukan rute kota didapatkan dengan menggunakan metode nearest neighbor dengan titik awal didapatkan secara acak. Dengan metode ini kota pertama diacak dari semua kota yang ada lalu kota selanjutnya didapatkan dengan mencari jarak terdekat dan belum pernah dikunjungi. Sedangkan solusi awal untuk barang bawaan dibiarkan kosong yang bertujuan untuk mendapatkan hasil yang lebih fleksibel.

\section{1.3 Selesksi Pemilihan Low Level Heuristic Menggunakan Simple Random}

Solusi awal yang didapatkan pada langkah sebelumnya akan diolah menggunakan sepuluh low level heuristic yang didapatkan dari jurnal [10]. Untuk LLH pada pemilihan barang yang akan dibawa didapatkan melalui jurnal [4]. Metode pemilihan menggunakan metode simple random, pada metode ini akan diacak nilai sebanyak jumlah LLH yang digunakan dari nilai tersebut dipilih LLH nomor berapa yang akan digunakan pada pengolahan dalam iterasi tersebut. Pada setiap pemilihan LLH untuk rute akan selalu berpasangan dengan LLH untuk barang bawaan. Untuk penelitian ini digunakan dua skenario percobaan yaitu hanya menggunakan LLH dengan metode Hill Climbing (HC) dan LLH dengan move acceptance atau metode hyper-heuristic.

LLH yang digunakan pada barang adalah memilih secara acak satu titik dan mengganti nilai titik tersebut jika nilai awalnya 0 maka menjadi 1 dan sebaliknya. LLH yang digunakan dalam perubahan rute sebagai berikut.

LLH1: Dua kota dipilih dan bagian tur dibalik antara dua kota yang dipilih ini. Ini dilakukan di setiap kota, mulai dari kota awal.

LLH2: Sepasang kota akan dipilih dari tur. Ini dilakukan di setiap kota, mulai dari kota awal. Misalnya, kota dan kota 3 dengan kota 2 dan kota 6 dan kota 7 dipilih. Gerakan 2-opt dilakukan di rute.

LLH3: Perpindahan 2-opt akan dilakukan, tetapi kota-kota dipilih secara acak.

LLH4: Dua kota dipilih secara acak dan mereka akan bertukar posisi. Sebagai contoh; kota 2 dan 7 dipilih. Kota 2 dan 7 akan bertukar posisi.

LLH5: beroperasi sama seperti LLH2. Langkah pertama yang menghasilkan perbaikan atas solusi saat ini akan diterima. 
LLH6: Dua kota dipilih dan membalikkan tur antara dua kota yang dipilih ini. Contohnya seperti di LLH1, bagaimanapun, prosedur dilakukan pada kota yang dipilih secara acak.

LLH7: Dua kota dipilih secara acak dan mereka akan bertukar posisi. Contohnya seperti pada LLH4. Prosedur ini akan diterapkan berulang kali hingga tidak ada perbaikan lebih lanjut.

LLH8: Dua kota mulai dari dua ujung akan dipilih dan bertukar posisi. Kota-kota di antara akan dibalik. Prosedur ini akan dilakukan di semua kota. Contohnya seperti pada LLH2. Peningkatan terbaik akan dicatat.

LLH9: Dua kota mulai dari dua ujung akan dipilih dan bertukar posisi. Prosedur ini akan dilakukan di semua kota. Contohnya seperti pada LLH4. Peningkatan terbaik akan dicatat.

LLH10: Dua kota yang dimulai dari dua ujung akan dipilih dan kota di antara akan dibalik. Prosedur ini akan dilakukan di semua kota. Contohnya seperti pada LLH1. Peningkatan terbaik akan dicatat.

\section{1.4 Move Acceptance dengan Tree Physiology Optimization}

Langkah selanjutnya ketika pemilihan LLH telah dilakukan adalah move acceptance. Langkah ini dilakukan untuk memenuhi model hyper-heuristik secara umum yaitu mempunyai langkah LLH selection dan move acceptance [11]. Pada langkah move acceptance ini digunakan algoritma tree physiologi optimization [7] untuk mengolah data. langkah move acceptance ini digunakan jika selama empat iterasi secara beruntun tidak menghasilkan nilai fitness yang lebih baik. Empat iterasi beruntun ditetapkan untuk tetap memberi ruang pada LLH yang pengerjaannya lebih cepat namun tetap seimbang dengan menggunakan TPO pada move accepatance untuk menghasilkan nilai yang lebih baik dengan pengerjaan yang lebih memakan waktu daripada LLH. Jika setelah move acceptance dan LLH tetap tidak ada perubahan selama 100 iterasi beruntun maka akan dilakukan penukaran titik kota dan barang secara acak dan menyimpan nilai fitness terbaik sementara. Nilai ini akan dibandingkan dengan setiap nilai fitness yang dihasilkan nanti. Nilai fitness terbaik akan diambil sebagai hasil akhir. Algoritma TPO digunakan untuk mengolah rute yang merupakan permasalahan TSP. Prosedur TPO dapat dilihat pada gambar 1.TPO pada model ini dimodifikasi agar menjadi berbasis solusi tunggal di mana sebelumnya berbasis populasi. Hal ini dilakukan untuk membuat waktu pengerjaan menjadi lebih cepat dan menyesuaikan dengan mode yang dibuat.

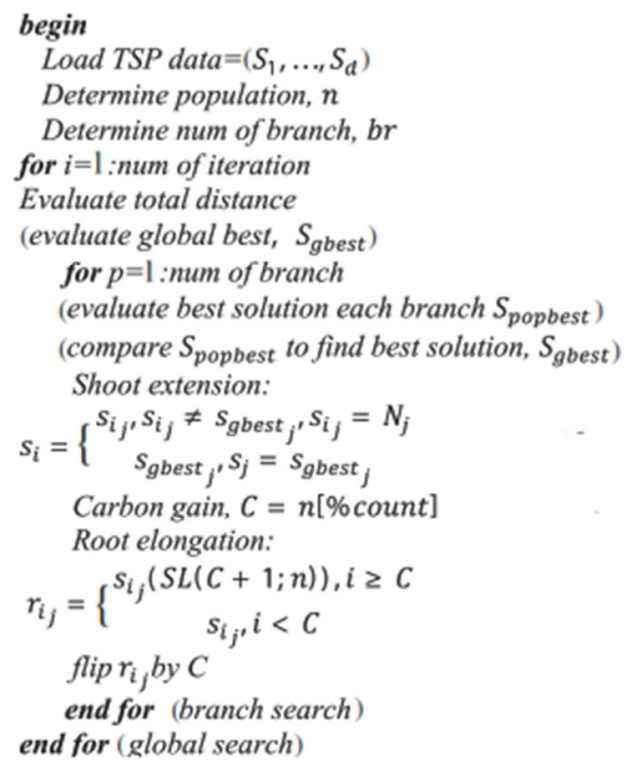

Gambar 1. Algoritma TPO

Lanang Alun Nugraha, et., al [Optimasi Travelling Thief Problem Menggunakan Algoritma Tree Physiology Optimization Berbasis Hiper Heuristik] 
Prosedur pengolahan data menggunakan metode LLH TPO dengan pemodelan hyperheuristic dapat dilihat pada flowchart di gambar 2. Pada gambar ini dijelaskan bahwa memulai dengan membuat solusi awal kemudian mengolah solusi awal dengan memilih LLH dengan metode simple random. Setelah LLH yang telah dipilih maka hasil akan di optimasi berdasarkan langkah LLH yang dipilih. Kemudian hasil optimasi akan dievaluasi apakah lebih baik atau tidak. Jika lebih baik maka dilakukan pemilihan LLH kembali pada iterasi baru. Jika tidak lebih baik selama empat kali beruntun maka diolah menggunakan TPO pada langkah move acceptance. Jika solusi lebih baik maka disimpan jika tidak lebih baik dan beruntun selama 100 iterasi maka akan diolah dengan pengacakan rute dan hasil terbaik tetap disimpan untuk dibandingkan dengan nilai fitness yang baru.

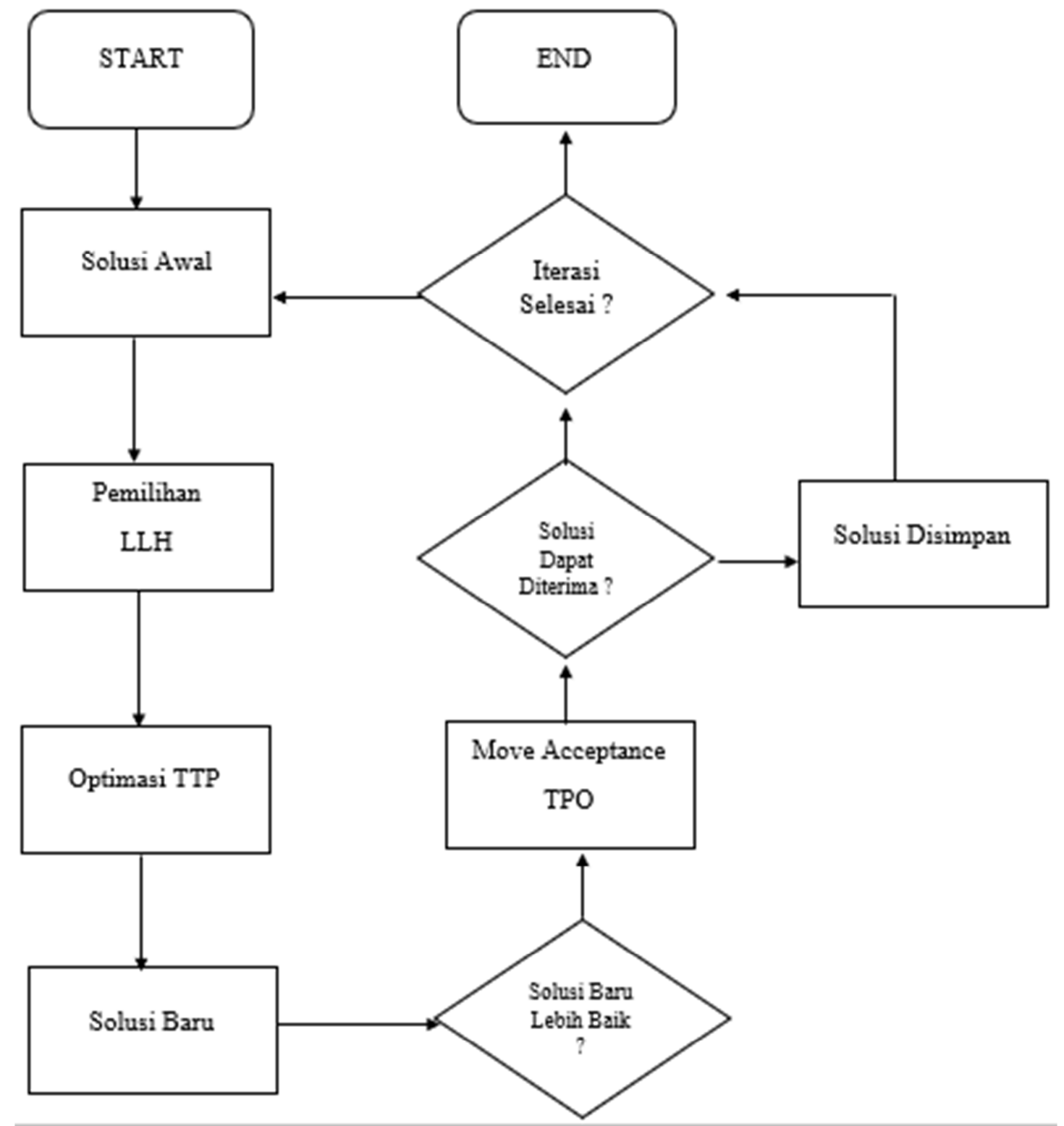

Gambar 2. Flowchart Alur LLH TPO 


\section{2 Implementasi Algoritma}

Algoritma yang telah dihasilkan diimplementasikan dalam bahasa pemrograman java dengan menggunakan program NetBeans IDE 8.2. Pada tujuh dataset yang digunakan akan dijalankan pengetesan sebanyak sepuluh kali pada setiap dataset. Waktu maksimal setiap pengetesan adalah 10 menit, waktu ini berlaku pada setiap dataset.

\section{3 Analisis Hasil}

Hasil dari implementasi algoritma yang telah dilakukan pada langkah sebelumnya akan dianalisis dengan membandingkan hasil pada skenario dengan menggunakan LLH HC, LLH TPO dan GPHS yang didapatkan pada jurnal [4]. Perbandingan hasil penyebaran 10 kali percobaan tiap dataset pada LLH HC dan LLH TPO yang dilakukan akan disajikan dalam bentuk grafik boxplot untuk melihat konsistensi hasil pada kedua metode ini.

\section{HASIL DAN PEMBAHASAN}

Setelah dilakukan percobaan pada tujuh dataset di mana setiap dataset dijalankan sebanyak sepuluh kali dengan algoritma LLH HC dan LLH TPO didapatkan hasil berupa nilai fitness dengan rata-rata hasil dan nilai terbaik yang dapat dilihat pada tabel 2 dan perubahan nilai LLH HC dibanding LLH TPO dapat dilihat pada tabel 3. Selain itu perbandingan nilai pada setiap iterasi dengan menggunakan dataset Berlin 52 juga disajikan dalam gambar 3 . Penyebaran data dalam bentuk boxplot pada kedua algoritma dapat dilihat pada gambar 4 dan 5 . Dan hasil dari perbandingan LLH HC, LLH TPO, dan GPHS dapat dilihat pada gambar 6.

Tabel 2. Perbandingan Hasil LLH HC Dengan LLH TPO

\begin{tabular}{|l|c|c|c|c|}
\hline & \multicolumn{2}{|c|}{ LLH HC } & \multicolumn{2}{c|}{ LLH TPO } \\
\hline Instance & Best & Avg & Best & Avg \\
\hline Eil 51 & 4033,506 & 3473,191 & $\mathbf{4 2 0 9 , 2 8 5}$ & $\mathbf{4 0 8 1 , 9 9 9}$ \\
\hline $\begin{array}{l}\text { Berlin } \\
\text { 52 }\end{array}$ & 4031,638 & 3298,248 & $\mathbf{4 2 0 5 , 0 5 9}$ & $\mathbf{4 1 2 9 , 0 0 1}$ \\
\hline Eil 76 & 3053,056 & 2368,944 & $\mathbf{3 6 9 5 , 8 3}$ & $\mathbf{3 5 7 0 , 2 2 6}$ \\
\hline $\begin{array}{l}\text { KroA } \\
\text { 100 }\end{array}$ & 4091,145 & 3048,292 & $\mathbf{4 8 8 2 , 1 7 9}$ & $\mathbf{4 4 6 1 , 2 8 1}$ \\
\hline A280 & $\mathbf{1 6 3 6 5 , 9 5}$ & 14672,86 & 16140,99 & $\mathbf{1 5 1 0 5 , 4}$ \\
\hline Pr439 & 29294,63 & 26290,55 & $\mathbf{3 0 4 6 3}$ & $\mathbf{2 7 8 5 9 , 5 7}$ \\
\hline Rat768 & 29689,26 & 25273,46 & $\mathbf{3 1 0 0 7 , 7 5}$ & $\mathbf{2 8 5 5 7 , 8 2}$ \\
\hline
\end{tabular}

Tabel 3. Perubahan Nilai dari LLH HC Dibanding LLH TPO

\begin{tabular}{|l|c|c|}
\hline Instance & Best & Avg \\
\hline Eil 51 & $+4,4 \%$ & $+17,5 \%$ \\
\hline Berlin 52 & $+4,3 \%$ & $+25,2 \%$ \\
\hline Eil 76 & $+21,1 \%$ & $+50,7 \%$ \\
\hline KroA 100 & $+19,3 \%$ & $+46,4 \%$ \\
\hline A280 & $-1,4 \%$ & $+2,9 \%$ \\
\hline Pr439 & $+4,0 \%$ & $+6,0 \%$ \\
\hline Rat768 & $+4,4 \%$ & $+13,0 \%$ \\
\hline
\end{tabular}




\section{Perbandingan Hasil Berlin 52}

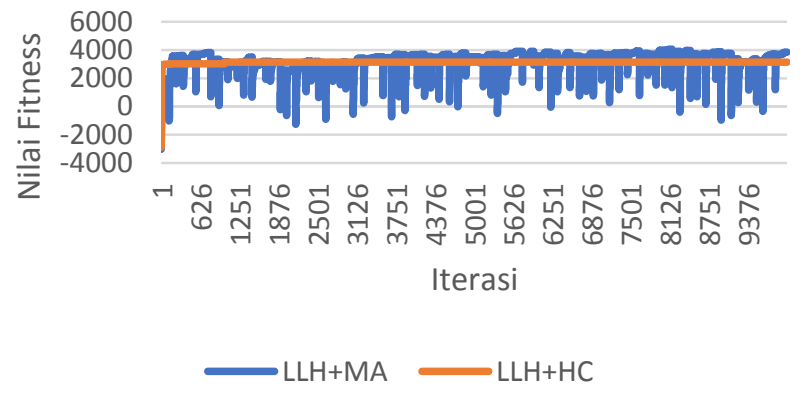

Gambar 3. Hasil Perbandingan Nilai Fitness pada Data Berlin 52

Berdasarkan hasil dari algoritma LLH HC dan LLH TPO / MA dapat dilihat bahwa algoritma LLH TPO menghasilkan nilai rata-rata yang lebih bagus pada semua dataset dibandingkan dengan algoritma LLH HC dan untuk nilai terbaik juga unggul di semua dataset kecuali Eil 76. Jika dilihat dari perbandingan hasil fitness tiap iterasi menggunakan data Berlin 52 algoritma LLH HC hanyak mengalami kenaikan pada awal iterasi hingga iterasi ke 557 setelah itu hanya mengalami sedikit kenaikan pada iterasi 1113, setelah iterasi ke 1113 tidak terjadi kenaikan hingga akhir iterasi yang menandakan sedang terjebak di local optimum. Sedangkan pada algoritma LLH TPO dapat dilihat bahwa perubahan nilai fitness dari awal hingga akhir iterasi dinamis yang dapat menandakan juga tidak terjebak dengan local optimum. Untuk nilai fitiness yang dihasilkan juga lebih baik daripada LLH HC dan dapat sedikit demi sedikit naik pada iterasi yang besar. Untuk kerapatan hasil percobaan yang dilakukan 10 kali pada setiap data dapat dilihat pada gambar 3 dan 4 jika algoritma LLH TPO menghasilkan kerapatan data yang lebih rapat daripada LLH HC. Pada data berukuran kurang dari 100 perbedaan kerapatan terlihat cukup signifikan, menandakan bahwa LLH TPO menghasilkan nilai yang lebih konsisten daripada LLH HC. Secara umum dapat dilihat bahwa dari berbagai segi algoritma LLH TPO lebih baik daripada algoritma LLH HC. Hal ini dikarenakan algoritma LLH TPO mempunyai langkah move acceptance dan pengacakan rute dan barang yang memungkinkan untuk lepas dari local optimum. Sehingga ketika iterasi dengan jumlah besar dijalankan data akan terus berusa mencari nilai global optimum.

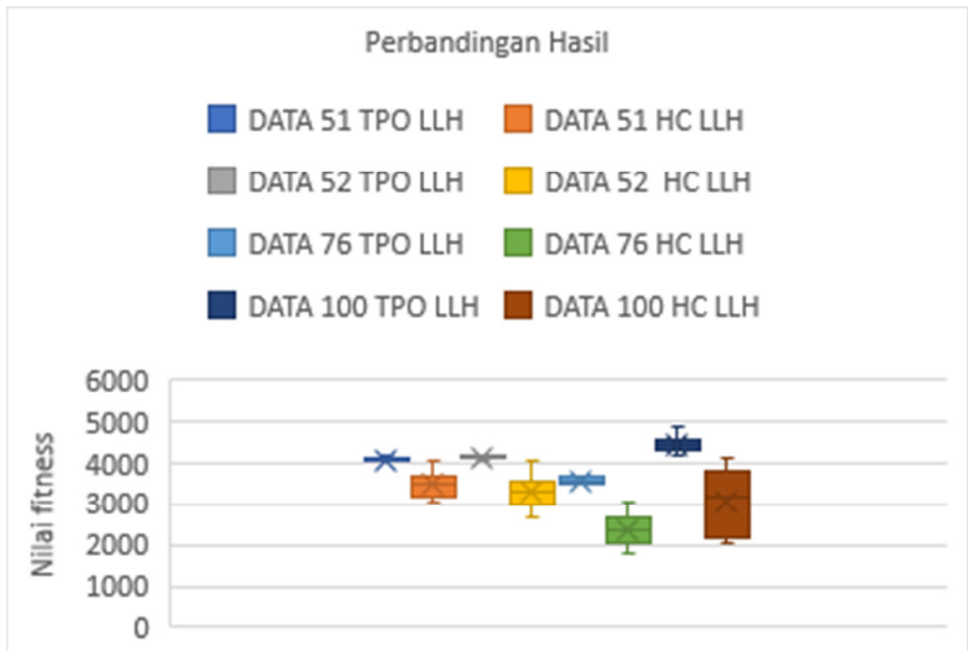

Gambar 4. Boxplot Perbandingan Hasil LLH HC Dengan LLH TPO 1

Lanang Alun Nugraha, et., al [Optimasi Travelling Thief Problem Menggunakan Algoritma Tree Physiology Optimization Berbasis Hiper Heuristik] 


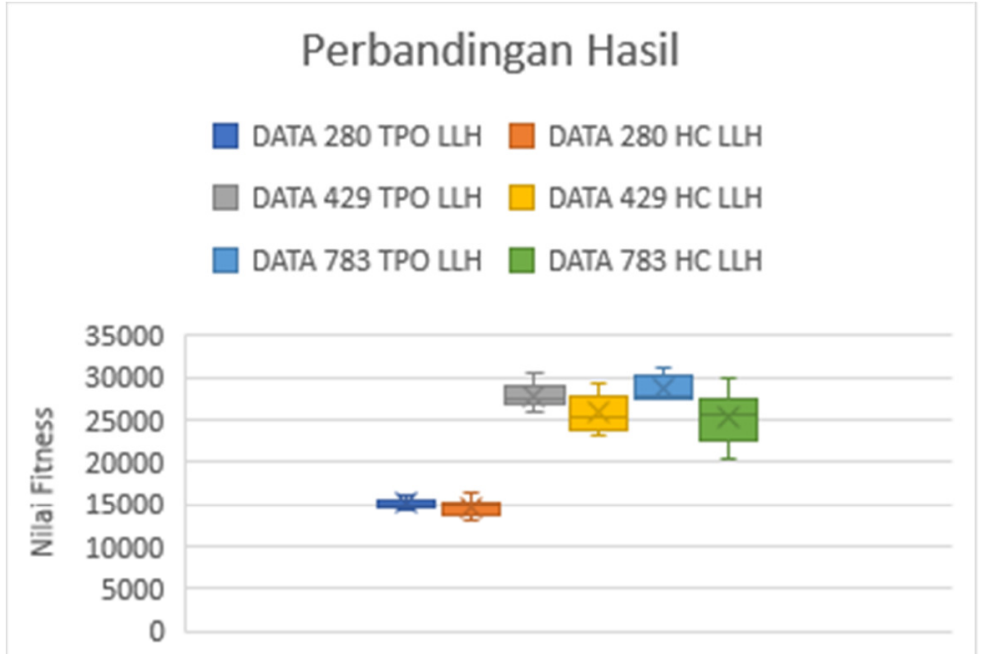

Gambar 5. Boxplot Perbandingan Hasil LLH HC Dengan LLH TPO 2

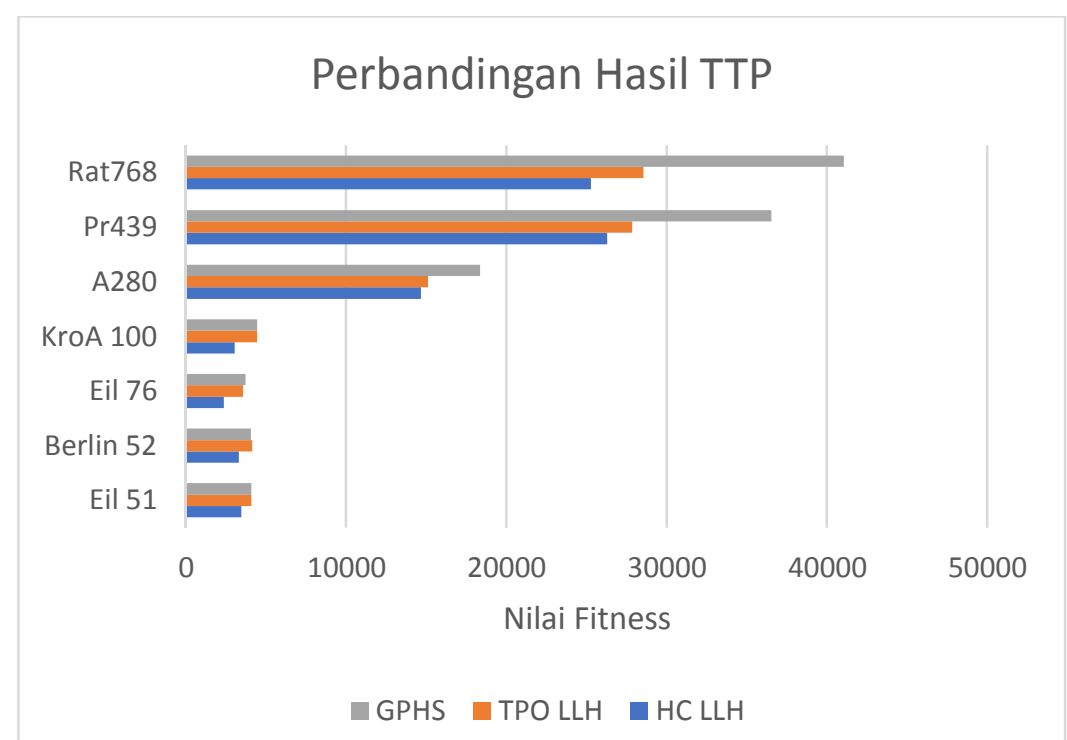

Gambar 6. Hasil Perbandingan Fitness TPO LLH, HC LLH, dan GPHS

Berdasarkan gambar 5 dapat dilihat bahwa pada data berukuran 51,52, dan 100 algoritma LLH TPO mendapatkan hasil terbaik dari semua algoritma. Untuk data berukuran $76,280,439,768$ nilai terbaik dihasilkan oleh algoritma GPHS. berdasarkan hasil fitness dapat disimpulkan bahwa algoritma yang diusulkan yaitu LLH TPO dapat bersaing dengan algoritma GPHS yang telah menghasilkan nilai tinggi pada semua dataset. Pada data rendah LLH TPO berhasil mengungguli nilai dari algoritma GPHS. 


\section{KESIMPULAN}

Kombinasi antara pemilihan low level heuristic (LLH) dan algoritma tree physiologi optimization (TPO) untuk permasalahan travelling thief probelm (TTP) diusulkan pada penelitian ini. Simple Random digunakan pada proses pemilihan LLH sementara TPO digunakan pada langkah move acceptance sehingga memenuhi kriteria Hyper-Heuristic yang memiliki penyeleksian LLH dan move acceptance. Kesimpulan dari kombinasi algoritma yang diterapkan yaitu:

Kombinasi dari seleksi LLH dengan simple random dan algoritma TPO pada langkah move acceptance berhasil diimplementasikan dan dapat memenuhi hard constraint pada tujuh dataset TTP yang digunakan. Pada penelitian ini dilakukan dua skenario yaitu LLH dengan hill climbing dan LLH dengan TPO. Dari hasil perbandingkan dua metode tersebut didapatkan bahwa penambahan move accepatance dengan menggunakan TPO dan pengacakan rute dan barang ketika hasil berulang dapat meningkatkan nilai fitness menjadi lebih baik, hal tersebut terbukti dari peningkatan hasil rata-rata di ketujuh data yang dilakukan. Hasil eksperimen pada dataset berukuran 51,52, dan 100 menunjukkan bahwa Kombinasi dari seleksi LLH dengan simple random dan algoritma TPO pada langkah move acceptance dapat mencapai solusi yang lebih baik dari metode genetic programming based hyper-heuristic (GPHS) hasil pada jurnal [4].

Dari hasil ini dapat disimpulkan bahwa algoritma LLH TPO dapat mengolah data dengan ukuran sedang dengan cukup baik. Hasil eksperimen pada dataset 76,280,439,786 menunjukkan bahwa algoritma GPHS yang dikembangkan pada jurnal [4] memiliki nilai yang lebih baik dari algoritma LLH TPO yang dikembangkan pada penelitian ini. Dari hasil ini dapat disimpulkan pada data dengan ukuran besar algoritma LLH TPO masih kurang baik dalam mengolah data dibandingkan algoritma GPHS.

\section{SARAN}

Kombinasi dari seleksi LLH dengan simple random dan algortima TPO pada langkah move acceptance berhasil diimplementasikan dalam kerangka hyper-heuristic namun pada pengimplementasiannya dengan dataset berukuran besar masih belum mendapatkan hasil yang lebih baik dibanding jurnal [4] .Untuk penelitian selanjutnya diharapkan penyesuaian pemilihan dan variasi LLH serta modifikasi dari TPO dapat dilakukan. Hal ini bertujuan untuk membuat metode menghasilkan nilai yang lebih baik pada data berukuran besar serta kestabilan hasil ratarata di semua data.

\section{DAFTAR PUSTAKA}

[1] M. R. Bonyadi, Z. Michalewicz, and L. Barone. 2013, "The Travelling Thief Problem: The First Step In The Transition From Theoretical Problems to Realistic Problems," 2013 IEEE Congr. Evol. Comput. CEC 2013, pp. 1037-1044.

[2] R. Matai, S. Singh, and M. Lal. 2014, "Traveling Salesman Problem: an Overview of Applications, Formulations, and Solution Approaches," Travel. Salesm. Probl. Theory Appl., No. January.

Lanang Alun Nugraha, et., al [Optimasi Travelling Thief Problem Menggunakan Algoritma Tree Physiology Optimization Berbasis Hiper Heuristik] 
[3] K. W. Ross and D. H. K. Tsang. 1989, “The Stochastic Knapsack Problem,” IEEE Trans. Commun., Vol. 37, No. 7, pp. 740-747.

[4] M. El Yafrani, M. Martins, M. Wagner, B. Ahiod, M. Delgado, and R. Lüders. 2018, “A hyperheuristic Approach Based on Low-Level Heuristics for The Travelling Thief Problem," Genet. Program. Evolvable Mach., Vol. 19, No. 1-2, pp. 121-150.

[5] J. Wu, M. Wagner, S. Polyakovskiy, and F. Neumann. 2017, "Exact Approaches For The Travelling Thief Problem," arXiv, pp. 110-121.

[6] A. H. Halim and I. Ismail. 2019, "Combinatorial Optimization: Comparison of Heuristic Algorithms in Travelling Salesman Problem,” Arch. Comput. Methods Eng., Vol. 26, No. 2, pp. 367-380.

[7] A. H. Halim and I. Ismail. 2017, "Tree Physiology Optimization in Benchmark Function and Traveling Salesman Problem,” J. Intell. Syst., Vol. 28, No. 5, pp. 849-871.

[8] F. B.-S. T. Sarra Zohra Ahmed Bacha, Mohamed Walid Belahdji, Karima Benatchba. 2019, “A New Hyper-Heuristic to Generate E$\square$ ective Instance GA for the.pdf.” pp. 13651374.

[9] S. S. Choong, L. P. Wong, and C. P. Lim. 2018, "Automatic Design Of Hyper-Heuristic Based On Reinforcement Learning,” Inf. Sci. (Ny)., Vol. 436-437, pp. 89-107.

[10] Z. A. Aziz. 2015, "Ant Colony Hyper-heuristics for Travelling Salesman Problem," Procedia Comput. Sci., Vol. 76, No. Iris, pp. 534-538.

[11] and J. R. W. Edmund K. Burke, Matthew Hyde, Graham Kendall, Gabriela Ochoa, Ender "Ozcan. 2010, "A Classification of Hyper-heuristic Approaches," Handbook of Metaheuristics, Vol. 146. p. 648. 